\title{
Foreign partner choice in the public interest: Experience and risk in infrastructure public- private partnerships
}

\author{
Bernadine J. Dykes ${ }^{1}$ and \\ Ikenna Uzuegbunam ${ }^{2}$
}

${ }^{1}$ School of Business, Shenandoah University, 1460 University Drive, Winchester, VA 22601, USA;

${ }^{2}$ Department of Management, School of Business, Howard University, 2600 6th Street NW,

Washington, DC 20059, USA

\section{Correspondence:}

BJ Dykes, School of Business, Shenandoah University, 1460 University Drive, Winchester, VA 22601, USA e-mail: bdykes@su.edu
Received: 6 April 2021

Revised: 17 January 2022

Accepted: 21 January 2022

Online publication date: 7 March 2022

\begin{abstract}
Infrastructure public-private partnerships (PPPs) are collaborative agreements between a public sector entity and private sector firm that are designed to build and operate infrastructure projects. This study explores how public-sector entity experience and institutional concerns impact the choice of a local or foreign private sector partner. We find that the public entity's prior infrastructure PPP experience has a U-shaped relationship with the likelihood of partnering with a foreign private sector firm. Meaning, we find that public entities with low and high levels of infrastructure PPP experience tend to partner with foreign private sector firms, whereas public entities with moderate levels of infrastructure PPP experience tend to partner with local private sector firms. Moreover, we find that financial risk associated with the infrastructure project moderates this relationship such that public entities with low or high levels of prior infrastructure PPP experience tend to partner with foreign private sector firms when the infrastructure project is highly leveraged. Our analysis of a global sample of project finance investments shows statistical support for our arguments. These findings regarding the determinants of PPP partner choice are significant given the massive investment in infrastructure development that is planned throughout the globe in the coming years.
\end{abstract}

Journal of International Business Policy (2023) 6, 47-66.

https://doi.org/ | 0.1057/s422I4-022-00 I34-z

Keywords: public-private partnerships; partner choice; prior experience; institutional environment

The National Council for Public-Private Partnerships has identified what it considers to be the six critical components of any successful P3... Of these six components, proper partner selection is one of the most critical elements for the long-term success of the partnership.

(California Debt and Investment Advisory Commission [CDIAC], March 2008)

Utilizing PPPs as a way of developing local private-sector capabilities through joint ventures with large international firms..." and "Using PPPs as a way of gradually exposing state-owned enterprises and government to increasing levels of private sector participation (especially foreign) ...

(Two of Eight Potential Benefits of PPPs outlined by The World Bank, 2016) ${ }^{1}$ 


\section{INTRODUCTION}

In recent years, scholars have increasingly gained interest in partnerships that exist at the intersection of public and private interests. These efforts to understand partnerships at the nexus of the public and private sector are deservedly encouraged by the proliferation and globalization of economic activity that integrates public and private interests (cf., Birch \& Siemiatycki, 2016; Mahoney et al., 2009) and by the blurring of sectoral boundaries between public and private sector economic activity (Birch \& Siemiatycki, 2016; Kivleniece \& Quelin, 2012; Linder, 1999; Mahoney et al., 2009). In this paper, we focus on a cornerstone of these hybrid, boundary-spanning activities - the infrastructure publicprivate partnership (PPP) - a unique form of public-private collaboration, where public interests are pursued through the participation of private sector firms to build infrastructure. Basically, infrastructure PPPs are cooperative arrangements between a public-sector entity (i.e., a host country or government) and private sector firm that are primarily used to finance, construct, and operate large infrastructure projects, such as toll roads, bridges, power plants, and water treatment facilities (Tang et al., 2010).

As highlighted in the first opening quote, one of the first critical steps in an infrastructure PPP is the selection of a private-sector partner (Hardcastle et al., 2005; Zhang \& Kumaraswamy, 2001; Zhang et al., 2019). Indeed, partner selection is a central decision in many forms of strategic partnerships because it has a significant bearing on the likelihood of successful outcomes from the partnership (Geringer, 1991; Hitt et al., 2000; Yayavaram et al., 2018). Public-sector entities select private-sector partners through an extensive request for proposal (RFP) process. Scholars and policy makers suggest that the managerial, financial, and operational capabilities as well as the place-specific network of the private sector firm, which are mostly detailed in the RFP, are significant factors in the partner choice decision because the private sector firm is the entity that is largely responsible for the design, construction, and management of the infrastructure asset (Berns et al., 2021; Hardcastle et al., 2005; Kolk et al., 2008; Siemiatycki, 2011; Zervos \& Siegel, 2008; Zhang et al., 2019). Hence, the current PPP literature argues that the public entity selects a private sector firm based on the strength of the firm's resources, skills, and expertise (Babatunde et al., 2012; Cabral, 2017; Kwak et al., 2009; Zhang, 2005b).

However, prescriptions related to resource or skill strength as the partner choice decision criteria are incomplete when considered against the backdrop of infrastructure PPPs that form across national borders. Cross-border PPPs, which have grown exponentially during the last several decades (PFI, 2014), are arrangements between public entities and foreign private-sector firms. Meaning, in crossborder infrastructure PPPs, the host-country partners with a private sector firm that is outside of its domestic market. Yet, many countries have a strong preference for local control (versus foreign control) of large and highly visible, infrastructure projects such as electricity grids, toll roads, etc. (Wells \& Gleason, 1995), especially countries with strong nationalist values. However, because local private sector firms are more embedded in the local institutional environment (North, 1990), they may suffer from institutional misalignment if environmental conditions change during the duration of the infrastructure project. International business scholars refer to this disadvantage as the liability of localness (Jiang \& Stening, 2013; PerezBatres \& Eden, 2008). In contrast, the decision to partner with a foreign firm in an infrastructure PPP is fraught with added complexity and additional political challenges. Foreign private sector firms may have access to unique resources, networks, and capabilities in their home market and offer more novel approaches to the design and operation of the infrastructure project (Edman, 2016; Shi \& Hoskisson, 2012), but they face higher costs of doing business in the local market (Hymer, 1960; Zaheer, 1995). Ultimately, the decision to partner with a foreign or local private sector firm is of critical importance because it directly influences the performance of the project (Dykes et al., 2020) and thus the economic development of the target community (Albala-Aschauer, 1989; Bertrand \& Mamatzakis, 2004; Elburz et al., 2017). Given the trade-offs and potential performance outcomes, when will a host-country partner with a foreign or local private sector firm in an infrastructure PPP? This paper confronts this question.

We draw from the organizational learning literature (Argote, 2011; Argote \& Miron-Spektor, 2011) and marry it with arguments from the institutional perspective (Kostova et al., 2008; North, 1990; Suddaby et al., 2017) to show how the level of prior infrastructure PPP experience of a public entity informs its sensitivity to the foreign versus 
local partner trade-off. Taken together, organization learning and institutional theorists suggest that experience confers legitimacy (Suddaby et al., 2017). Experienced organizations know how to conform to the expectations of the environment. They tend to have greater latitude of actions given their legitimacy with stakeholders. Herein, we extend this line of inquiry by suggesting that, based on a certain level of experience, organizations can manage their legitimacy in the infrastructure PPP domain to satisfy constituents (cf., Suchman, 1995). That is, we infer that organizations have varying levels of legitimacy based on experience and that experience permits entities to strategically manipulate whatever legitimacy they may have to make decisions in the public interest. Specifically, we propose a U-shaped relationship between host-country infrastructure PPP experience and the likelihood of foreign private sector partner choice. On the one hand, increasing levels of experience amplifies the extent to which a host country is more inclined to partner with a local firm and thus reinforce its legitimacy in the local environment. On the other hand, as experience increases beyond moderate levels, host countries have exhausted the local resources and capabilities for infrastructure development, and thus need foreign participation. Meaning, highly experienced host countries have ample legitimacy in the infrastructure PPP domain to convince local stakeholders to accept a foreign private sector partner.

Further, we recognize that PPPs are complex undertakings, laden with risks across multiple levels and dimensions including risks at the project, country, and organizational level (Aritua et al., 2011; Finnerty, 2013; Osei-Kyei \& Chan, 2017; Vaaler et al., 2008; Wang et al., 2020; Xiong et al., 2017). Risk management of an infrastructure project is important because it impacts the performance of the project (Doloi, 2012). Herein, we focus on risks at the project level given the salient and very large amount of human capital and financial outlays directly related to the design, financing, operation, and maintenance of an infrastructure asset over the life of the project (Barlow \& Köberle-Gaiser, 2008; Finnerty, 2013; Kumaraswamy \& Morris, 2002; Yescombe, 2002). Projects with higher levels of risk require more experience and expertise to manage the risks. Hence, we argue that project risk will moderate the aforementioned curvilinear relationship.

This paper makes multiple contributions to the literature. First, we extend the infrastructure PPP and strategic partner selection literature by arguing that the partner choice decision is based on the trade-offs associated with a foreign or local partner (in addition to a decision based on the resource or skill strength of the private sector firm) (Hitt et al., 2000; Shah \& Swaminathan, 2008). The existing literature over-emphasizes the characteristics of the private sector firm (as critical success factors) without fully recognizing that the partner choice calculus is inherently more complicated when a foreign firm is a contender for the project. Wells and Gleason (1995) capture an aspect of this tradeoff by arguing that foreign firms will only emerge as PPP partners when the benefits clearly outweigh the economic and political costs. In essence, we argue that prior infrastructure PPP experience of the public entity has additional explanatory power to predict the partner choice decision beyond arguments related to the capabilities and expertise of the private sector firm. By situating the partner choice decision in the determination of a cross-border PPP, our work highlights how prior experience shapes the likelihood of engaging a foreign partner through balancing the need for local support and involvement with the need for outside knowledge and capabilities.

Second, our work adds to existing research that explores how organizations manage legitimacy in order to satisfy stakeholders depending on their level of experience (cf., Kacperczyk \& Younkin, 2017). Historically, organizational theorists asserted that legitimacy is relatively stable, takenfor-granted, and conferred unto other entities (Deephouse \& Suchman, 2008; Suchman, 1995). Our perspective departs from this traditional view and supports a more agentic and malleable view of legitimacy (Suddaby et al., 2017). In the context of infrastructure PPPs, we argue that, based on their level of experience, public entities actively manage their legitimacy in the public interest in order to gain support from stakeholders. In essence, our work hints that organizations may use their legitimacy to influence stakeholder perceptions and outcomes. Hence, our study presents a boundary condition regarding how legitimacy operates in the life of public sector organizations.

Third, we extend the literature that examines the effect of risk on learning and experience (Argote \& Miron-Spektor, 2011). We do so by arguing that the level of financial and ownership risk in an infrastructure project influences the relationship between experience and partner choice. Depending on the type of project risk, more risky projects may 
encourage experienced host countries to partner with a particular type of partner to redirect the additional risks of the project while still capturing the benefits of the project. Hence, our paper suggests that varying levels of uncertainty in a particular context can disrupt or distort the effects of prior experience in decision-making (Baird \& Thomas, 1985; Sitkin \& Pablo, 1992). Finally, our paper responds to a call to better understand how the global context impacts infrastructure PPPs (cf., Babatunde et al., 2012; Chan et al., 2010; Mahoney et al., 2009).

To test our predictions, we utilize an international sample of project finance investments, which are the primary means to finance infrastructure PPPs. Our findings demonstrate support for the key hypothesis regarding a U-shaped relationship between prior experience and the decision to partner with a foreign private sector firm. Our findings also show that financial risk encourages very experienced host countries to partner with foreign private sector firms whereas ownership risk appears to have no effect on the relationship between experience and partner choice. We begin with a review of the partner choice literature in infrastructure PPPs followed by hypotheses related to the main effect of prior experience and the moderating effect of two different types of project risk on the partner choice decision. Next, we discuss our empirical results. To conclude, we discuss the implications of our findings for scholars, practitioners, and policy makers.

\section{PRIVATE SECTOR PARTNER SELECTION IN INFRASTRUCTURE PPPS}

Partner selection is a critical step in the formation of an infrastructure PPP. As with other types of strategic partnerships, the partner choice decision is conducted in the early phase of the project. Host countries tender requests for proposals (RFPs) to invite private sector firms to consider participation in an infrastructure project. Host countries partner with private sector firms based on multiple criteria, including the private sector firm's resources, skills, experience, capabilities, and place-specific network (Berns et al., 2021; Zhang, 2005a, 2005b). For example, based on a sample of projects in the United Kingdom and China, researchers found that successful infrastructure PPP outcomes often hinge on the managerial strength of the private sector partner (Li et al., 2005; Osei-Kyei \& Chan, 2015; Zhang, 2005a). Additionally, private sector firms with stable and committed social networks can enhance the success of an infrastructure PPP (Berns et al., 2021; Siemiatycki, 2011). Taken together, the current PPP literature often takes the perspective that the partner choice decision is based on the resource and network strength of the private sector firm.

However, the partner choice decision is more complex in cross-border infrastructure PPPs due to the potential involvement of foreign participants in these long-term contracts. First, some countries prefer local private sector firm participation. This preference exists because local control and ownership (compared to foreign ownership and control) of an infrastructure project often satisfies the interests of local stakeholders who want residual control rights and growth opportunities that stem from the infrastructure project. Further, partnering with a local private sector firm might generate stronger economic development in the host country because the local firm enjoys local networks (Berns et al., 2021; Siemiatycki, 2011) and other location-specific advantages (Alcácer \& Chung, 2011; Dunning, 1998), which may speed the completion time of the infrastructure project (Dykes et al., 2020). Thus, by partnering with a local firm, the host-country institutions and agents stand to enhance legitimacy among their local stakeholders (Di Maddaloni \& Davis, 2018; Freeman, 2010; Phillips, 2003) and satisfy public interests.

Additionally, the host country is a strategic partner in the infrastructure PPP, which means that the resources, incentives, and support it provides to the private firm (primarily, logistical, and regulatory support) inherently involve the use of public funds. Thus, host countries have a fiduciary and critical responsibility to serve and safeguard the interests of their local stakeholders (Bennett \& Iossa, 2006a, 2006b; Freeman, 2010; Phillips, 2003; Thomas, 1998). For infrastructure projects, these stakeholders may include environmental groups, supply chain providers, local politicians, and the general public. One of the chief means through which host countries fulfill their fiduciary responsibility to their stakeholders is by supporting policies and investments that promote the economic well-being of the domestic market. When a hostcountry partners with a local private sector firm, the benefits of the infrastructure PPP are primarily generated and maintained in the domestic market. However, when a host country chooses a foreign private sector firm in an infrastructure PPP, the host country shares a part of the benefits of the 
infrastructure project with an entity that is outside of the domestic market. Therefore, cross-border infrastructure PPPs, by their very nature, create unique tensions for the host country because it must demonstrably serve and protect the public interest in the local environment and share the part of the benefits of the infrastructure project with a foreign partner.

Thus, we propose that the partner choice decision in cross-border infrastructure PPPs is more aptly based on the trade-offs associated with partnering with a local or foreign firm. In the following section, we examine arguments from organizational learning and institutional economics to explain how the host country understands and exploits the nuances associated with these tradeoffs.

\section{PRIOR INFRASTRUCTURE PPP EXPERIENCE AND LEGITIMACY EFFECTS}

The management literature argues that organizations learn from their own experience (Argote, 2011; Argote \& Miron-Spektor, 2011). This learning from experience creates a stockpile of knowledge that the organization can apply to complex environments, including international business environments. (Forbes, 2005; Li \& Meyer, 2009; Lu et al., 2014; Perkins, 2014). The stock of knowledge also forms the basis for capabilities, routines, and cognitive schemas that can be used to store, recall, and interpret information. Firms can use their combinative capabilities to create new knowledge from existing knowledge (Kogut \& Zander, 1992, 1993). More importantly, accumulated knowledge from experience can help a firm manage risks and uncertainties, exploit opportunities, and build legitimacy (cf., Chang \& Rosenzweig, 2001). This knowledge and experience can be transferred within and across organizations to provide the most benefit. This generally positive effect of learning has been found in multiple international business settings (Barkema et al., 1996; Berry \& Sakakibara, 2008; Perkins, 2014).

Learning via experience in the infrastructure PPP context suggests that, over time, host countries experiment with different inputs (e.g., money, construction materials, etc.), incentives, and processes (e.g., tender preparation, evaluation of bids, negotiations of concessions, etc.). Consequently, they learn which strategic options are the most efficient and effective for producing the desired outputs. Because infrastructure PPPs are complex and long-term undertakings, organizations tend to codify the knowledge gained from experience, which in turn makes access to the knowledge more accessible and repeatable (Kogut \& Zander, 1992). Critically, as host countries undertake more infrastructure PPP projects, they accumulate knowledge about which criteria may lead to the best private sector partner - an important decision in the PPP process.

Moreover, prior experience can confer legitimacy on the decisions of organizations. This is because prior experience conveys a sense of knowledge, confidence, and stability to external stakeholders. This type of legitimacy is akin to what scholars call "traditional" legitimacy because it is based on organizational duration or longevity (Suddaby et al., 2017). Meaning, more-experienced entities may have ample legitimacy. Legitimacy is often viewed as a relatively stable attribute that is conferred by outside entities. Yet, organizations can have agency and thus actively manage their legitimacy (Elsbach, 1994; Elsbach \& Sutton, 1992). For infrastructure PPPs, we assert that one of the ways that public entities can manage their legitimacy is by aligning the private partner selection with the needs and interests of the public and other infrastructure PPP stakeholders (cf., Baik \& Park, 2019). In the sections below, we elaborate on how public entities use prior experience and legitimacy to satisfy the interests of their constituents through the private sector partner choice.

\section{HYPOTHESIS DEVELOPMENT}

We argue that host countries with little prior PPP experience will be more likely to partner with a foreign private sector firm. First, less-experienced host countries are less knowledgeable about doing business with a foreign entity (March, 1999; Petersen et al., 2008) and thus, they do not understand the liabilities and risks that foreign firms may bring to the partnership (Hymer, 1960; Zaheer, 1995). International business scholars propose that foreign firms face certain liabilities and additional costs due to their "foreignness" or unfamiliarity with the local environment. These liabilities include local biases against foreign firms, information asymmetries and the inability to communicate cross-culturally or manage across diverse organizational structures (Eden \& Miller, 2001; Luo \& Mezias, 2002; Zaheer, 1995). Instead, the lessexperienced host country might be more openminded to working with a foreign firm because it 
presents an opportunity to learn and apply new approaches to infrastructure development. For instance, the government of India, which had limited PPP activity prior to 2005, partnered with an Austrian firm (Strabag AG) to build a highway tunnel in 2014. India attributed the success of the tunnel to Strabag's cutting-edge tunneling method of construction. ${ }^{2}$ On the surface, it may appear that an inexperienced host country would be very interested in placating its local stakeholders in order to develop or boost its limited legitimacy in the domestic market (Reimann et al., 2012). However, less-experienced host countries are less knowledgeable about how to identify and respond to the appropriate infrastructure PPP stakeholder groups. Thus, the less-experienced host country will more likely seek the rewards and assume the risks of partnering with a foreign private sector firm.

As infrastructure PPP experience accumulates, however, the host country is more knowledgeable about the liabilities and costs of "foreignness" (Hymer, 1960; Mezias, 2002; Miller \& Parkhe, 2002; Zaheer, 1995). Thus, the host country will be less willing to partner with a foreign private sector firm. More importantly, because of their additional experience with infrastructure development, host countries with more infrastructure PPP experience will likely be more knowledgeable about how to fulfill the needs and interests of local stakeholders and, at the same time, be less interested in learning new infrastructure development approaches. Essentially, host countries with moderate levels of PPP experience will tend to avoid the risks and forego the potential rewards of foreign private sector partners. Instead, they will reinforce their legitimacy with the local environment by partnering with a local private sector firm.

Beyond moderate levels of experience, host countries will have a higher likelihood of partnering with a foreign private sector firm. After years of experience, host countries may have exhausted the resources and capabilities of local firms for infrastructure development (Biygautane et al., 2019; Hitt et al., 2000; North, 1990), which in turn leads to the need for foreign investment. For example, in 2014, Finland partnered with an international firm to construct a motorway between Hamina and Vaalimaa, which are municipalities that connect Finland with Russia. The Finish government was forced to seek international participation because its domestic market lacked adequate infrastructure contractors and financiers. ${ }^{3}$ Given the long duration and resource intensity of most infrastructure projects, local firms may not be able to replenish quickly enough and/or adequately enough to meet the demands of the local infrastructure environment even if they desire to do so. Further, highly experienced public entities have abundant legitimacy in the infrastructure PPP domain. Such host countries have the legitimacy to assist a foreign firm in overcoming the liabilities of foreignness (Biygautane et al., 2019; Hymer, 1960; Zaheer, 1995; Zaheer \& Mosakowski, 1997). For instance, the highly experienced public entity can smoothen the acquisition of construction permits and licenses or help build relationships and rapport with local engineers and developers. Further, host countries with high levels of experience have the information processing capacity to absorb and integrate the divergent knowledge bases of the foreign private sector firm (Cohen \& Levinthal, 1990; Kogut \& Zander, 1992; Zahra \& George, 2002), and thus can learn novel techniques and practices from the foreign private sector firm. To repeat, it may appear that a host country that partners with a foreign private sector firm would upset its local stakeholders. However, we argue that highly experienced host countries can leverage their abundant legitimacy to convince their local stakeholders (through knowledge dissemination about the foreign firm) to accept a foreign private sector partner in an infrastructure PPP. Hence,

Hypothesis 1: Host-country experience has a Ushaped relationship with the likelihood of selecting a foreign partner in an infrastructure PPP project.

\section{Risks and Complexities of Infrastructure PPPs}

PPPs involve an immense amount of risk at multiple levels for stakeholders (Esty, 2004; Finnerty, 2013; Wells \& Gleason, 1995; Yescombe, 2002), including projects in global environments (Kardes, Ozturk, Cavusgil, \& Cavusgil, 2013; Miller, 1992). For instance, the potential cash flows from the infrastructure project can make the project susceptible to expropriation from the host government (Sawant, 2010). Relatedly, institutional factors, such as economic risks, rule of law, and political risks, can have a direct impact on the ability of the project to create value (Meyer \& Peng, 2005). Industry factors such as equity ownership concentrations are risks to the infrastructure project. Lower levels of equity ownership among the private sector investors increase the risk of project failure or 
non-payment to project creditors (Vaaler et al., 2008). This is due to the fact that lower levels of equity ownership often lead to less governance and oversight of the infrastructure project. Finally, based on a sample from the United Kingdom, scholars found that infrastructure projects are also subject to risks associated with changes in the diversity of stakeholder aspirations (Aritua et al., 2011).

Herein, we focus on risks at the project level. Infrastructure projects are typically very capitalintensive, location-specific, and lengthy in duration. As a result, the opportunities for risk and uncertainty to develop are salient, large, and complex at the project level. For instance, infrastructure construction requires contractors to identify topographical difficulties before construction begins, which often requires large equipment, significant software investments, and substantial materials to mitigate. Further, infrastructure projects require demand forecasting (Flyvbjerg et al., 2003), which often necessitates weeks or months of review and research to develop appropriately. Combined, these issues often result in budget and time overruns, which risks the financial success and/or operational completion of the infrastructure project (Esty, 2004).

In the next sections, we argue that host countries need experience and expertise to manage the risks in infrastructure development. We argue that two of the major types of risks in the infrastructure project are financial risk and ownership risk.

\section{Financial Risk in Infrastructure PPPs}

Infrastructure PPPs require substantial capital outlays and investment from private sector partners, public entities, contractors, and financial institutions (Esty, 2002; Finnerty, 2013). The financial capital is used to acquire labor, construction equipment and materials, permits and/or licenses as well as legal, architectural, and other advisory services. The vast majority of infrastructure PPPs are financed with loans or bonds from banks and other global financial institutions (Finnerty, 1996; Yescombe, 2002). Typically, the project may also obtain a portion of its financing from the host country in the form of bonds or grants, but the brunt of the debt is still borne by the project company (Demirag et al., 2012). The project company, which is formed by the private sector partner, is a special-purpose entity that is created to manage and finance the infrastructure project. The cash flows from the underlying infrastructure asset are used to service the debt of the project. Higher levels of debt mean the infrastructure project is at greater risk of being unable to generate enough cash flow to meet its financial obligations, such a loan repayment (cf., Demirag et al., 2011).

Higher levels of financial risk in the infrastructure project require broader and deeper skills, knowledge, and expertise to manage the risks (Marshall et al., 1996). We expect that moreexperienced host countries involved in projects that tend toward higher levels of financial risk (i.e., debt) will be more knowledgeable about the potential impact of the financial riskiness of the project. Unlike their less-experienced counterparts, moreexperienced host countries have the knowledge and/or the capacity to absorb and process the expertise that is needed to manage the heightened risks of the project (Cohen \& Levinthal, 1990; Zahra \& George, 2002).

More importantly, more-experienced host countries (compared to less-experienced host countries) have such a greater understanding of the significant financial risk associated with the infrastructure project that they use their legitimacy to redirect this risk away from their local environment (Kardes et al., 2013), while still maintaining the benefits of the project. Infrastructure development benefits the local environment by stimulating local job creation, supporting human development, spurring entrepreneurial activity and/or promoting domestic economic growth (Elburz et al., 2017; Sears et al., 1990). Experienced host countries can retain these benefits by requiring the use of local suppliers for key project materials, for example. More importantly, host countries that partner with a foreign private sector firm seek to redirect the financial risk of the project to the foreign partner and its stakeholders (which are based in the foreign firm's home market). For instance, experienced host countries may require that financial institutions based in the foreign firm's home market finance a large portion of the project. This sort of stipulation is no small feat given that most infrastructure projects are financed by multinational banks that typically spread credit risk across markets (Bedendo \& Bruno, 2012). However, the experienced host country has enough legitimacy in the PPP domain to garner support for this type of financial arrangement. Shifting financial risk to environments outside of the local market has political ramifications because it helps to appease local stakeholders. Hence, the financial risk of an infrastructure project will moderate the relationship between host- 
country experience and the likelihood of foreign partner choice such that as financial risk increases, the U-shaped relationship between host-country experience and the likelihood of a foreign partner choice becomes more positive, especially at very high levels of infrastructure PPP experience. Therefore,

Hypothesis 2: Host-country experience has a stronger U-shaped relationship with the likelihood of selecting a foreign partner in an infrastructure PPP project with higher levels of financial risk.

\section{Ownership Risk in Infrastructure PPPs}

Several organizational types of PPPs exist in terms of whether the infrastructure asset is ultimately owned and operated by the private sector firm or eventually transferred to the host country (Finnerty, 2013; Yescombe, 2002). Build-operate-own (BOO) projects are projects in which the ownership of the constructed asset remains with the private sector firm throughout its life. BOO projects pose less risk to the host country because the private sector firm bears the risks and costs of ongoing operation and maintenance of the infrastructure asset. By contrast, with BOT projects (build-operatetransfer), the private sector firm builds the asset, owns and operates it for a certain period, and then transfers ownership of the asset to the host country. BOT projects pose more risk to the host country because the host country bears the risks and costs of ongoing asset ownership and control.

We expect that more-experienced host countries involved in infrastructure PPPs with higher levels of ownership risk (i.e., BOT projects) will be less inclined to partner with a foreign private sector firm. Similar to higher levels of financial risk, higher levels of ownership risk also require broader and deeper expertise and skills to manage the risks (Marshall et al., 1996; Miller, 1992). However, unlike financial risk, ownership risks primarily accrue after construction is complete. The postconstruction period is the period when the host country will start to earn cash flows from the project. These cash flows are designed to offset the risks and costs of project ownership. More-experienced host countries understand the potential for financial gains to offset the ownership risks and will seek to shield these gains from foreign appropriation by partnering with a local firm and thereby appease local stakeholders and reinforce their legitimacy in the local market (Contractor \& Woodley, 2015). Alternatively, less-experienced host countries involved in infrastructure PPPs with higher levels of ownership risk will not have the information-processing capabilities (Tushman \& Nadler, 1978) or expertise to fully evaluate and understand the risk/reward trade-offs during the post-construction period. Instead, they will only focus on protecting their home market from the potential risks and thus lean toward partnering with a local private sector firm. Therefore,

Hypothesis 3: Host-country experience has a weaker U-shaped relationship with the likelihood of selecting a foreign partner in an infrastructure PPP project with higher levels of ownership risk.

\section{METHOD}

We test our hypotheses using a sample of project finance investments, which are the primary means through which infrastructure PPPs are financed. The life of a project finance investment begins when a host-country partners with a private sector firm, which may be a foreign or local firm, to construct an infrastructure asset. Project finance investments may involve a consortium of private sector firms. In this study, however, we focus on bilateral projects in which the private sector firm is the sole private sector firm in direct partnership with the host country. Focusing on these types of projects allows us to better identify the effect of host-country experience with a single private sector partner without the confounding influence of other partners.

The sample is based on project finance investments across 26 host countries, 46 home countries (associated with the private sector firms), and ten project sectors for the focal infrastructure projects. The host countries include both developed and developing countries. The ten industries include power, telecommunications, oil and gas, leisure and property, mining, transportation, waste, water and sewer, agriculture, and petrochemicals. Our analysis focuses on infrastructure projects that were completed because host counties are likely to have more legitimacy with PPP stakeholders for completed projects. The projects cover the period 1990-2003. We focus on this time period so that we can capture the growth and potential completion of infrastructure projects before the global financial crisis of 2007.

We obtained the project finance data from Project Finance International (PFI); a Refinitiv (formerly Thomson Reuters) database that contains worldwide information on project finance investments. For the full sample, approximately $27 \%$ of 
our observations involved projects led by foreign private sector firms while the remaining 73\% involved projects led by local private sector firms. This distribution in the dependent variable highlights that although may public entities choose a local firm, a sizeable proportion of these public entities chose to work with a foreign firm. In terms of project sectors, the power sector is the largest segment; representing approximately $43 \%$ of the full sample. Approximately, $27 \%$ of the power projects were led by partnerships between host countries and foreign private sector firms, whereas partnerships between host countries and local private sector firms led approximately $73 \%$ of the power projects for the full sample.

\section{Dependent Variable}

\section{Foreign or local private sector firm}

In an infrastructure PPP, the private sector firm creates a special-purpose vehicle called a project company. The project company is a separate legal entity that manages the relationships, financing, as well as the operation of the project in the host country. Once the project is complete, the project company is dissolved. The project company is not a local subsidiary of the private sector firm that may have been operating in the host country for many years prior to the focal infrastructure project. Rather, the project company is a temporary organization of the private sector firm and thus has an identity that closely mirrors that of the private sector firm (Bakker, 2010). The implication is that foreign project companies are genuinely "foreign" and local project companies are genuinely "local" in the host environment.

Following existing work (Mezias, 2002; Miller \& Parkhe, 2002; Zaheer, 1995), our measure of foreignness is based on the geographic location of the project under construction (i.e., the host country) and the geographic headquarters of the sole private sector firm that partnered with the host public entity. We coded project finance investments between the host country and a foreign private sector firm (i.e., project company) with a 1 and all others with a 0 .

\section{Independent Variable}

Prior infrastructure PPP experience of the host country We measured the host country's level of prior infrastructure PPP experience by counting the number of project finance investments in which the focal host country was involved prior to the focal project (cf., Luo, 1997; Oetzel \& Oh, 2014;
Sampson, 2005). This measure captures the host country's prior infrastructure PPP experience across all sectors in its local environment in the 5 years prior to the start of the focal project. We use count measures because organizational learning theorists use counts to measure experience, particularly in strategic partnerships (cf., Hoang \& Rothaermel, 2005; Luo, 1997; Oetzel \& Oh, 2014; Sampson, 2005). We use a 5-year window because the average completion time of the infrastructure projects in the sample is less than 5 years. Hence, the highest benefit of prior experience was likely to occur within a 5 -year window.

\section{Moderating and Control Variables}

\section{Financial risk}

Project finance investments are primarily funded with debt (Finnerty, 1996). We measured this variable based on the project's percentage of financing secured with debt.

\section{Ownership risk}

To reiterate, $\mathrm{BOO}$ projects are infrastructure projects in which the private sector firm retains control and ownership of the asset after construction is complete. BOT projects are infrastructure projects in which the private sector firm transfers control and ownership of the asset to the public entity after construction is complete. We coded BOO projects with a 0 and BOT projects with a 1 .

\section{Prior infrastructure PPP experience of the private sector firm}

We used the prior infrastructure PPP experience of the private sector firm as a proxy for the firm's expertise, resources, and capabilities. Following existing research, we measured the private sector firm's level of infrastructure PPP experience by counting the number of project finance investments in which the focal firm was involved prior to the focal project (cf., Luo, 1997; Oetzel \& Oh, 2014; Sampson, 2005). This measure captures PPPs across all sectors and countries in the 5 years prior to the start of the focal project. To repeat, we use a 5-year window because the average completion time of the infrastructure projects in the sample is less than 5 years. Hence, the highest benefit of prior experience was likely to occur within a 5-year window.

\section{Project size}

The project size reflects the cost of the project finance investment in millions of U.S. dollars. 


\section{GDP growth of the host country}

We controlled for GDP growth of the host country to account for any differences in the institutional development of the host environments. Countries with higher levels of GDP growth may have launched more infrastructure PPPs. We measure GDP growth 1 year prior to the focal project. We obtained GDP data from the World Bank.

\section{Project sector and year dummies}

Project finance investments occur across many different project sectors and years - any of which may significantly impact economic growth. Thus, we used project sector and year dummies to allow for the possibility that unobserved characteristics associated with project sector (e.g., technical complexity) or year could be driving our results.

\section{Analysis}

We focus on understanding on how the hostcountry experience impacts the infrastructure PPP partner decision. Table 1 shows the summary statistics and the correlation table. All observations are at the project level of analysis. However, we note that some countries had multiple project finance investments in our sample, which suggests that not all observations are independent (cf., Sampson, 2007). Thus, we clustered error terms by country. Furthermore, we note that all variance inflation factors were below the ten point cut-off $(\max$ VIF $=5.26$; mean VIF $=2.29)$ (Cohen et al., 2003), indicating that multicollinearity is unlikely to be an issue. We centered all independent variables before creating the interaction terms (Cohen et al., 2003).

Because our dependent variable is dichotomous, we use probit analysis. Extant research shows that the difference between probit versus logit models is modest (Chambers \& Cox, 1967). Yet, for robustness, we analyzed our data using the logit function and achieved a similar pattern of results.

Strategy and organizational scholars, in recent methodological papers, have focused attention on the appropriate ways of interpreting results of limited dependent variable (LDV) models (i.e., either probit or logit models) (Hoetker, 2007; Wiersema \& Bowen, 2009; Williams, 2009). In OLS models, researchers report and interpret the beta coefficients for the variables of interest. However, LDV models are intrinsically nonlinear, which makes the interpretation of the results more subtle than the results from OLS models. For LDV models, current research suggests that scholars also report

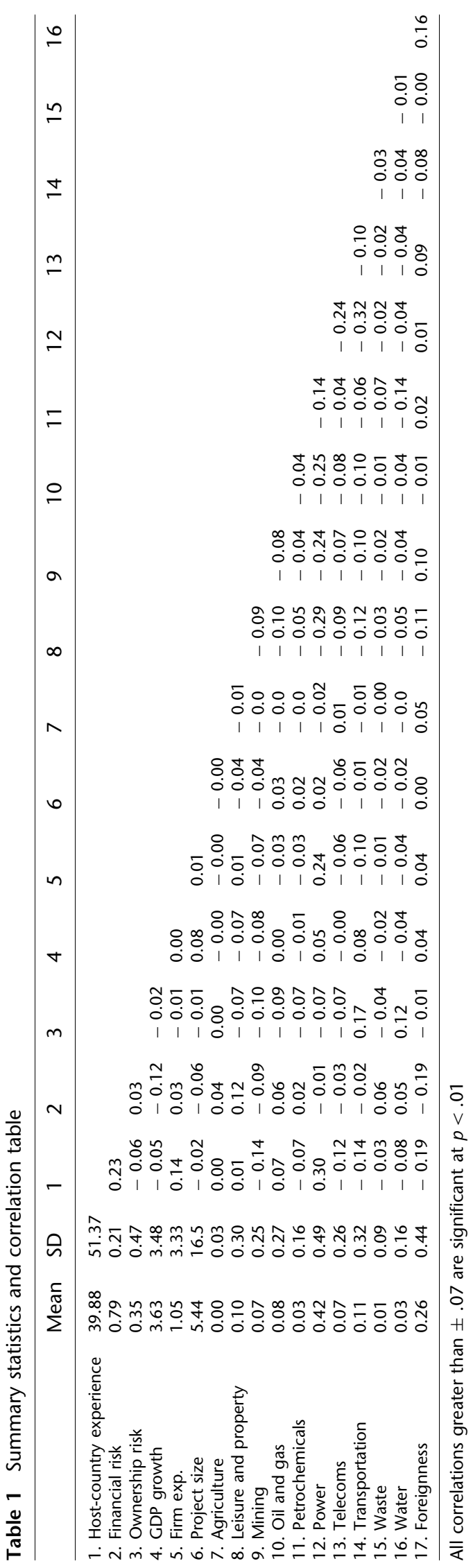


and interpret the marginal effects for the variables of interest (Hoetker, 2007; Wiersema \& Bowen, 2009; Williams, 2009). Thus, we use the "margins" function in Stata 17 and base the interpretation of our results on statistical significance ( $p$ values) and marginal effects of each model as shown in Table 2. We also note that the significance of the marginal effects in LDV models is not determined by the $p$ value alone (as is the case with OLS results). Instead, the significance of the marginal effects is best done graphically by plotting the marginal effects against the predicted values of the dependent variable (i.e., probability of partnering with a foreign or local private sector firm) (cf., Wiersema \& Bowen, 2009). Hence, we also confirm the significance of our results by evaluating the graphs associated with each of our hypotheses.

\section{RESULTS}

In Table 2, Model 1 presents the control variables only. Model 2 presents the controls, host-country experience, and the squared term of host-country experience. Model 3 presents all variables in Model 2 and the interaction of financial risk and squared host-country experience. Model 4 presents all variables in Model 2 and the interaction of ownership risk and squared host-country experience. Model 5 in Table 2 includes all variables of interest; thus, we interpret our results based on Model 5.

In Hypothesis 1, we argued that host-country experience would have a U-shaped relationship with the likelihood of partnering with a foreign firm. In Model 5, host-country experience is negative and significant (marginal effect $=-0.01$; $p<.01)$ and the squared term of host-country experience is positive and significant (marginal effect $=0.0001 ; p<.05)$. Inexperienced host countries and highly experienced host countries partner with foreign private sector firms whereas host countries with moderate levels of experience partner with local private sector firms. Inexperienced firms do not have sufficient expertise and legitimacy to respond to local infrastructure PPP stakeholders effectively, so they opt for foreign participation in the infrastructure project. Alternatively, host countries with high levels of experience have ample knowledge and legitimacy to garner local support for a foreign partner and to mitigate the additional costs of partnering with a foreign firm. Host countries with moderate levels of experience partner with a local firm and thus reinforce their legitimacy. Figure 1 shows a U-shaped relationship between host-country experience and the likelihood of partnering with a foreign private sector firm. Therefore, H1 is supported.

In Hypothesis 2, we argued that financial risk would positively moderate the U-shaped relationship between host-country experience and the likelihood of partnering with a foreign firm. In Model 5, the interaction between financial risk (i.e., project debt) and the squared term of host-country experience is positive and significant (marginal effect $=0.001 ; p<.01)$. In Figure 2 , we dichotomized our financial risk variable (debt $=0$ or 1 ) because our analysis of this variable indicates that there is a clear distinction between projects with all debt and those with a mix of debt and equity.

Our prediction in Hypothesis 2 was that highly experienced host countries would partner with foreign private sector firms in projects with high debt levels. Figure 2 supports our arguments. The graph shows that at high levels of host-country experience, host countries in highly leveraged projects tend to partner with foreign private sector firms. Meaning, host countries with highly leveraged projects seek to shift the financial risk in the infrastructure project away from the local environment and thus pacify local interests. Therefore, $\mathrm{H} 2$ is supported.

In Hypothesis 3, we argued that ownership risk would negatively moderate the U-shaped relationship between host-country experience and the likelihood of partnering with a foreign firm. In Model 5, the interaction between ownership risk and the squared term of host-country experience is negative, but nonsignificant. Therefore, H3 is not supported.

\section{Robustness Checks}

For robustness, we performed several additional analyses. To repeat, we analyzed our data using the logit function instead of the probit function. Second, we measured host-country experience using a 10-year experience window. Third, we controlled for the country experience of the private sector firm (instead of overall infrastructure PPP experience). Country experience is the prior infrastructure PPP experience of the private sector firm within the host country of the focal project in 5and 10- year time frames. Our robustness checks yielded a similar pattern of results as shown in Table 2.

Further, we conducted a split sample analysis of our data based on two criteria: host-country income and host-country geographic region. Earlier, we noted that our data contain projects in 
Table 2 Probit regression (marginal effects results); error terms clustered by country

\begin{tabular}{|c|c|c|c|c|c|}
\hline & M1 & $\mathrm{M} 2$ & M3 & M4 & M5 \\
\hline Host country Exp. & & $-0.004^{* *}$ & $-0.01^{\star *}$ & $-0.004^{* *}$ & $-0.01^{\star *}$ \\
\hline Host country Exp.^2 & & $0.001 \dagger$ & $0.001 *$ & $0.001^{*}$ & $0.001^{*}$ \\
\hline Host country $\exp ^{\wedge} 2$ * & & & $0.001^{* *}$ & -0.001 & $0.001^{* *}$ \\
\hline Financial risk & & & & & -0.001 \\
\hline \multicolumn{6}{|l|}{ Host country $\exp ^{\wedge} 2^{*}$} \\
\hline \multicolumn{6}{|l|}{ Ownership risk } \\
\hline Financial risk & & & $-0.41^{* \star *}$ & 0.02 & -0.42 \\
\hline Ownership risk & & & & & 0.06 \\
\hline Fin risk*host country exp & & & $-0.01 \dagger$ & & $-0.01 \dagger$ \\
\hline Own risk*host country exp & & & & 0.001 & 0.001 \\
\hline Project size & -0.001 & -0.00 & -0.001 & -0.001 & -0.001 \\
\hline GDP growth & 0.00 & 0.01 & 0.004 & $0.01^{*}$ & 0.004 \\
\hline Firm Exp & 0.01 & 0.01 & 0.01 & $0.01 \dagger$ & 0.01 \\
\hline Year dummies & $\mathrm{a}$ & $A$ & $\mathrm{a}$ & $\mathrm{a}$ & $\mathrm{a}$ \\
\hline Project sector dummies & $\mathrm{a}$ & A & $a$ & $a$ & $\mathrm{a}$ \\
\hline Pseudo R-squared & 0.05 & 0.08 & 0.10 & 0.09 & 0.11 \\
\hline $\mathrm{N}$ & 1076 & 1076 & 509 & 1076 & 509 \\
\hline
\end{tabular}

${ }^{\dagger} p<.10 ;{ }^{*} p<.05 ;{ }^{* *} p<.01 ;{ }^{* * *} p<.001$

a These controls are included in all models, but the results are not shown for the sake of parsimony

Table 3 Host countries and \# of infrastructure projects

\begin{tabular}{|c|c|c|}
\hline Host country & No. of projects & Percentage (\%) \\
\hline Australia & 84 & 8 \\
\hline Brazil & 66 & 6 \\
\hline Canada & 47 & 4 \\
\hline Chile & 23 & 2 \\
\hline China & 34 & 3 \\
\hline Colombia & 17 & 2 \\
\hline France & 17 & 2 \\
\hline Germany & 15 & 1 \\
\hline Hong Kong & 10 & 1 \\
\hline Hungary & 15 & 1 \\
\hline India & 60 & 5 \\
\hline Indonesia & 44 & 4 \\
\hline Japan & 16 & 1 \\
\hline Malaysia & 37 & 3 \\
\hline Mexico & 44 & 4 \\
\hline Peru & 10 & 1 \\
\hline Philippines & 29 & 3 \\
\hline Poland & 22 & 2 \\
\hline Russian Federation & 23 & 2 \\
\hline South Africa & 15 & 1 \\
\hline South Korea & 17 & 2 \\
\hline Spain & 20 & 2 \\
\hline Thailand & 18 & 2 \\
\hline United Kingdom & 132 & 12 \\
\hline United States & 274 & 25 \\
\hline Venezuela & 15 & 1 \\
\hline \multirow[t]{2}{*}{ Vietnam } & 14 & 1 \\
\hline & 1,118 & 100 \\
\hline
\end{tabular}

developed and developing countries. Infrastructure projects in developing countries operate in different institutional environments and face different types and levels of risk, which may impact the partner choice decision. ${ }^{4}$ Thus, we divided our sample between developed and developing countries based on the host country of the infrastructure project. We used information from the World Bank to code each host country as either high or low income in the year the infrastructure project was announced. Based on this split sample analysis, we found a similar pattern of results as found in Model 2 of Table 2 for developing countries. However, the results for developed countries were nonsignificant. Meaning, our subsample analysis suggests that the effects from developing countries may be driving the overall results related to Hypothesis 1 . We were surprised by this finding because we would have expected host countries in developing countries to generally prefer a foreign private sector partner (regardless of experience level) due to a lack of infrastructure contractors and investors in the local market. It appears that in the context of infrastructure PPPs, some host countries in developing markets may be inclined to develop local market participants. However, we interpret these results with caution because the sample size in the subsample analysis was small for developing and developed countries. Relatedly, the small subsamples prevented us from achieving significant results 
Figure 1 Curvilinear effect of host-country experience.
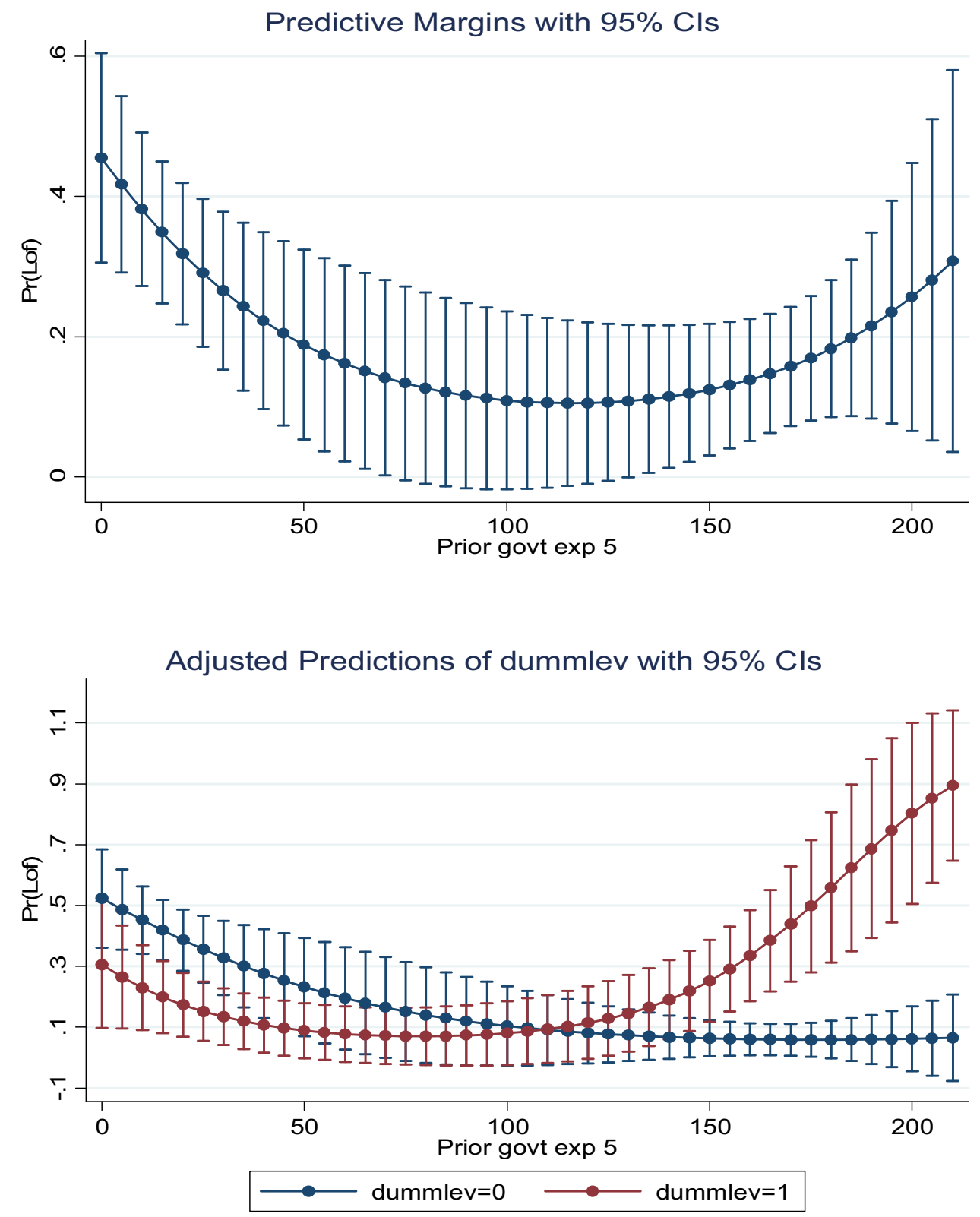

Figure 2 Moderating effect of financial risk. primarily driven by projects in Asia. We offer suggestions for future research related to this finding in the discussion section of the paper.

\section{DISCUSSION}

The purpose of this study was to evaluate whether prior infrastructure PPP experience predicts whether a host country will partner with a foreign or local private sector firm. We also evaluated whether the financial and ownership risk in the infrastructure PPP project moderates the relationship between host-country infrastructure PPP experience and partner choice. Our study was motivated 
Table 4 Infrastructure projects by region

\begin{tabular}{lcc}
\hline Region & No. of projects & Percentage (\%) \\
\hline Europe & 244 & 22 \\
North America & 365 & 33 \\
Latin America/Caribbean & 131 & 12 \\
Asia & 363 & 32 \\
Middle East \& Africa & 15 & 1 \\
& 1,118 & 100
\end{tabular}

Table 5 Infrastructure projects by sector

\begin{tabular}{lc}
\hline Sector & Percentage (\%) \\
\hline Power & 40 \\
Transportation & 11 \\
Oil \& gas & 9 \\
Leisure \& property & 9 \\
Telecommunications & 8 \\
Mining & 7 \\
Petrochemicals & 4 \\
Water \& sewer & 3 \\
Waste & 1 \\
Agriculture & 1 \\
Other & 7 \\
& 100
\end{tabular}

by the growth in cross-border PPPs since the 1990s (PFI, 2014) as well as an increased global attention to infrastructure development in general (Lundan \& Leymann, 2021). Most importantly, our study was motivated by the need to understand why a host country would potentially risk upsetting its local stakeholders and constituents by partnering with a foreign private sector firm.

We leveraged arguments related to organizational learning (Argote, 2011; Levitt \& March, 1988) and institutional economics (Kostova et al., 2008; North, 1990) to suggest that prior infrastructure PPP experience predicts the extent to which host countries will partner with a foreign firm, while being constrained by the need to satisfy public interests. Our findings point multinational firms towards host countries that might be more open to collaboration based on prior experience. Our theoretical arguments are based on the learning-by-doing framework. However, we also recognize that our findings related to experience infer that inexperienced and experienced host countries may search more broadly, geographically, for a partner than moderately experienced host countries. That is, our findings hint at the possibility of exploring the relationship between experience and organizational search in future research (cf., Cyert \& March, 1963).

In our results, we found that entities with very low levels of experience were more likely to partner with a foreign firm. However, literature related to the myopia of learning (Levinthal \& March, 1993; Tsang, 2002) infers that inexperienced organizations would prioritize learning from near environments, which suggests that inexperienced firms might be more likely to partner with a local firm. Indeed, we find that the results from the subsample analysis support the notion that inexperienced public entities tend to partner with local firms, but only in developing countries. Our findings thus point to an important boundary condition for organizational learning scholars. Organizations may overlook distant opportunities at certain experience levels in developing countries.

Importantly, our findings demonstrate that the need to satisfy local stakeholders, which tend to favor local firms in the PPP context, is sometimes outweighed by the need to seek new resources and capabilities from a foreign actor. Specifically, the study supports the proposition that there are at least two regimes when the forces of foreignness outweigh the local forces. In the first regime, the host country is a novice in the infrastructure PPP context and is inclined toward a foreign partner because of the lack of knowledge about the liabilities of foreignness. In the second regime, the host country is seeking new frontiers of PPP knowledge and capabilities.

Similarly, both of the aforementioned regimes hint at how public officials in host countries manage legitimacy. In the first regime, novice host countries fail to have enough legitimacy to pinpoint and understand the needs of the local stakeholders and thus partner with a foreign firm. In the second regime, the host country wields its abundant legitimacy to garner support for foreign participation among local stakeholders (cf., Biygautane et al., 2019). The latter case intimates that more experienced host countries may be manipulative in order to curry favor with local constituents. For future research, scholars may want to explore instances in which organizations use legitimacy based on questionable motives (cf., Elsbach \& Sutton, 1992). We also encourage scholars to explore more institutional concerns for infrastructure PPPs, such as the role of social actors throughout the life of the project (Biygautane et al., 2019). 
This study also suggests that financial risk moderates the U-shaped relationship between hostcountry experience and the likelihood of partnering with a foreign private sector firm. Our findings imply that experienced host countries may lean toward partnering with a foreign firm when the infrastructure PPP project is highly leveraged. These results extend prior research on strategic partnerships and alliances (cf., Hoang \& Rothaermel, 2005) by showing the effect of prior experience gained from infrastructure PPPs is contingent on risk factors in the focal project. The financial risk of a PPP project is a substantial risk factor, which a highly experienced host country might prefer to divert away from the domestic market. Importantly, this finding demonstrates that more-experienced host countries are likely to have more sophisticated risk management approaches that will limit the exposure of the local environment. For future research, scholars may want to explore other types of project risks as well as country or industry risks that may influence the partner selection decision.

Moreover, in our theorizing, we acknowledge that a large body of research recognizes that foreign firms may sometimes suffer from a liability of foreignness (LOF) due to unfamiliarity with the host-country environment (Hymer, 1960; Mezias, 2002; Miller \& Parkhe, 2002; Zaheer, 1995). Infrastructure PPPs are designed to create public benefits, which implies that host countries have an incentive (and the unique capability) to alleviate or redress any potential institutional forces that can constitute a liability for the foreign private sector firm. For example, by providing public sector resources (e.g., work permits, custom clearance for construction inputs, etc.), host countries reduce and consequently restructure market forces to work in the favor of their foreign partners. Our research suggests, however, that the willingness of a host country to disregard the liability of foreignness may depend upon the host country's level of infrastructure PPP experience. It appears that the quest to privatize public infrastructure through PPPs might offer inexperienced public entities some buffer to engage with a foreign partner as a means to addressing the resource and capability shortages in the local environment. Thus, our research helps specify a unique domain where any disadvantages that would ordinarily apply to foreign firms could be mitigated by the overwhelming need to serve the public interest.
Lastly, future research may also want to explore infrastructure projects in less developed parts of the globe, such as Latin America and Africa (Dykes \& Jones, 2016). Indeed, our subsample analysis of developing and developed countries points to opportunities to explore infrastructure PPPs in more detail. For instance, perhaps infrastructure PPPs between host countries in developing countries and private sector firms in developed markets (and vice versa) could be an area for future research. Similarly, our subsample analysis findings related to Asia suggest that Asia could be a market where more prominent issues related to infrastructure PPPs could be found. Relatedly, there is more opportunity to study cross-border PPPs exclusively to better understand the dynamics of communication, goal alignment and resource fit across cultures and geographies.

\section{IMPLICATIONS FOR GOVERNMENTS AND POLICY MAKERS}

Our findings have implications for policy makers, governments and global institutions involved in infrastructure PPPs. PPP stakeholders should be aware that the experience of the host country has an influence on the partner selection decision. Host countries may partner with a local or foreign private sector firm to aid in managing the uncertainties and intricacies of the infrastructure project. Our findings suggest that public officials should be sensitive to when local partners may be unable to fulfill the requirements of infrastructure PPP projects in a satisfactory manner and be willing to engage a foreign partner. Nevertheless, the host country should also be aware of the learning gains from infrastructure projects and be prepared to turn back to their local environment for partners when the appropriate learning threshold is reached. This points to the essential role of an integrating agency that monitors and coalesces knowledge and experience from infrastructure PPP projects in the local environment. Such as agency can be linked across different levels of government, since PPP projects can occur at either the local, state, or federal level. Moreover, the charter of this agency could include calibrating how project level risk might affect the suitability of a foreign or local private sector partner for the project.

The findings related to the moderating role of financial risk is also noteworthy for governments and practitioners. Governments and policy makers should be mindful that the level and type of risk 
involved in the infrastructure project influences the partner choice outcome. Moreover, infrastructure PPP stakeholders should be aware that the risks in the infrastructure PPP extend through the lifecycle of the project - from the very beginning of the project (i.e., partner selection), to the middle of the project (perhaps additional project financing) and to the end of the project (i.e., project completion and maintenance). Our study clearly isolates the salience of financial risk in the determination of whether a foreign or local partner is selected for the project. As such, government policy toward PPP projects should involve a high degree of actuarial oversight that will help put into place processes and procedures that will engender proper accountability on the financial risks of PPP projects.

The findings in our subsample analysis suggest that public entities in developing countries may be more inclined to partner with local private sector firms. Governments and policy makers in developing countries may be motivated to partner with local firms in order to promote domestic economic development. However, officials in developing countries should also be mindful that foreign participation in infrastructure development may also yield benefits, such as unique assets and knowledge (Shi \& Hoskisson, 2012).

Finally, in the coming years, project finance and infrastructure development is set to become a massive area of investment and attention across the globe for policy makers, governments and investors (Lundan \& Leymann, 2021). This increased attention and investment is driven by climate change, a basic need for infrastructure development, restoration and renovation as well as the global pandemic. COVID-19 has exposed significant deficits in public infrastructure in many countries around the world. For example, over 75\% of India's healthcare infrastructure is concentrated in metropolitan areas (where only $27 \%$ of the population lives). As a result, India faced significant challenges in dealing with the rapid spread of COVID-19 due to deficiencies in transporting vaccines and healthcare workers in rural areas. ${ }^{5} \mathrm{~A}$ similar issue exists in the healthcare systems in rural America, which has experienced a significant decline in its infrastructure, losing 130 hospitals between 2010 and 2020) (Fried et al., 2020). To address this concern, U.S. President Joe Biden signed a historic $\$ 1.2$ trillion infrastructure bill into law on November 15, 2021. The bill is expected to revolutionize American lives for years to come by upgrading the country's roads, bridges, water systems and broadband. Similarly, the European Union intends to invest up to 2 billion euros in infrastructure by $2027 .^{6}$ McKinsey \& Co. estimates that global infrastructure projects will require $\$ 3.7$ trillion annually through 2035 . $^{7}$

\section{LIMITATIONS}

Our study has some limitations. First, we recognize that other organizations facilitate learning, experience effects and risk management in PPPs throughout the life of the infrastructure project (Alcacer \& Ingram, 2013; Stadtler \& Probst, 2012). These organizations include the World Bank, United Nations, economic development groups and other international institutions. Because of data limitations, we are unable to identify which and when each type of entity may have been involved in our sample of infrastructure projects. Second, we assume that host countries always work for the good of public interests. However, prior work has shown that it is often difficult to reconcile private and public benefits in infrastructure projects (Kolk et al., 2008). Agency theorists would propose that host-country agents may use the latitude afforded by their positions in government to benefit their own self-interests, which often leads to unwanted behaviors, such as embezzlement, bribery, and other forms of corruption. Indeed, previous work demonstrates that there is some heterogeneity in host-country managerial discretion (FernándezMéndez et al., 2015). Further, we cannot eliminate the possibility that our results may be influenced by other institutional factors. For example, some entities may be more likely to partner with certain private sector firms based on the historical relationship between the home and host country. Due to the complexity of ties between countries (cf., Argyres et al., 2020; Jones \& Khanna, 2006; Makino \& Tsang, 2011), our study does not specifically account or control for the historical relationship between countries associated with the infrastructure PPP. Moreover, we recognize that infrastructure project risks may vary based on whether the host country is a developed or developing country. Unfortunately, as noted in our subsample analysis, we do not have enough power in our data to tease out these differing effects.

Finally, we recognize that host countries sometimes provide guarantees to the private sector partner as part of the financial package of an infrastructure project. Government guarantees are provisions that governments provide to mitigate 
against political, economic, or project-related risks. These guarantees are intended to attract private sector investment. However, these guarantees are not upfront cash outlays. Instead, they are contingent liabilities that may be payable in large amounts and in a short time period. Government guarantees could lower the financial risk in the infrastructure project for the private sector firm. Unfortunately, neither the PFI or World Bank datasets contain measures or proxies for government guarantees. Thus, we are unable to directly observe or measure the effect of any guarantees. However, we argue that guarantees add more complexity to the financial structure of the project for the government/host country because guarantees place more financial risk for the project on the government. Therefore, we would expect the results related to financial risk $(\mathrm{H} 2)$ to be even stronger for infrastructure projects with government guarantees.

\section{CONCLUSION}

In closing, we have offered an account of how infrastructure PPP projects - a cornerstone of activities that span the public and private sector boundaries-are shaped by the infrastructure PPP experience of the host country. By leveraging insights related to organizational learning and institutional economics, we highlighted how prior infrastructure PPP experience impacts the partner choice decision. We also examined critical boundary conditions on experience in the public interest

\section{REFERENCES}

Albala-Bertrand, J. M., \& Mamatzakis, E. C. 2004. The impact of public infrastructure on the productivity of the Chilean economy. Review of Development Economics, 8(2): 266-278.

Alcácer, J., \& Chung, W. 2011. Benefiting from location: Knowledge retrieval. Global Strategy Journal, 1(3-4): 233-236.

Alcacer, J., \& Ingram, P. 2013. Spanning the institutional abyss: The intergovernmental network and the governance of foreign direct investment. American Journal of Sociology, 118(4): 1055-1098.

Argote, L. 2011. Organizational learning research: Past, present and future. Management Learning, 42(4): 439-446.

Argote, L., \& Miron-Spektor, E. 2011. Organizational learning: From experience to knowledge. Organization Science, 22(5): 1123-1137.

Argyres, N. S., De Massis, A., Foss, N. J., Frattini, F., Jones, G., \& Silverman, B. S. 2020. History-informed strategy research: The promise of history and historical research methods in advancing strategy scholarship. Strategic Management Journal, 41(3): 343-368.

Aritua, B., Smith, N. J., \& Bower, D. 2011. What risks are common to or amplified in programmes: Evidence from UK public sector infrastructure schemes. International Journal of Project Management, 29(3): 303-312. by considering the moderating role of financial and ownership risks. As scholars grapple with understanding the behavior of organizations at the boundaries of the public and private sectors, the findings of our research help underscore the need to assess these questions in a more nuanced manner.

\section{NOTES}

${ }^{1}$ https://ppp.worldbank.org/public-privatepartnership/overview/ppp-objectives, accessed December 8, 2020.

${ }^{2}$ https://www.hindustantimes.com/cities/9-kmlong-atal-tunnel-an-engineering-marvel/storyhxYuskhbvkFAmQK1uQD1YK.html.

${ }^{3}$ https://www.bergmann.fi/e/article/ppp.

${ }^{4}$ We thank an anonymous reviewer for highlighting this possibility.

${ }^{5}$ This data is available from this Financial Express source: https://www.financialexpress.com/healthcare/ importance-of-public-private-partnership-in-buildinghealthcare-infrastructure/2385379/.

${ }^{6}$ https://www.cpr-am.fr/institutionals/Localcontent/Actualites-Presse-Recompenses/DecodingThe-European-infrastructure-plan.

${ }^{7}$ https://www.barrons.com/articles/future-returnsinvesting-in-private-infrastructure-assets-could-rise01629215464.

Aschauer, D. 1989. Is public expenditure productive? Journal of Monetary Economics, 23(2): 177-200.

Babatunde, S., Opawole, A., \& Akinsiku, O. 2012. Critical success factors in public-private partnership (PPP) on infrastructure delivery in Nigeria. Journal of Facilities Management, 10(3): 212-225.

Baik, Y., \& Park, Y.-R. 2019. Managing legitimacy through corporate community involvement: The effects of subsidiary ownership and host country experience in China. Asia Pacific Journal of Management, 36(4): 971-993.

Baird, I. S., \& Thomas, H. 1985. Toward a contingency model of strategic risk taking. Academy of Management Review, 10(2): 230-243.

Bakker, R. 2010. Taking stock of temporary organizational forms: A systematic review and research agenda. International Journal of Management Reviews, 12(4): 466-486.

Barkema, H. G., Bell, J. H., \& Pennings, J. M. 1996. Foreign entry, cultural barriers, and learning. Strategic Management Journal, 17(2): 151-166.

Barlow, J., \& Köberle-Gaiser, M. 2008. The private finance initiative, project form and design innovation: The UK's hospitals programme. Research Policy, 37(8): 1392-1402. 
Bedendo, M., \& Bruno, B. 2012. Credit risk transfer in US commercial banks: What changed during the 2007-2009 crisis? Journal of Banking \& Finance, 36(12): 3260-3273.

Bennett, J., \& lossa, E. 2006a. Building and managing facilities for public services. Journal of Public Economics, 90(10): 21432160.

Bennett, J., \& lossa, E. 2006b. Delegation of contracting in the private provision of public services. Review of Industrial Organization, 29(1-2): 75-92.

Berns, J. P., Gondo, M., \& Sellar, C. 2021. Whole country-oforigin network development abroad. Journal of International Business Studies, 52(3): 479-503.

Berry, H., \& Sakakibara, M. 2008. Resource accumulation and overseas expansion by Japanese multinationals. Journal of Economic Behavior \& Organization, 65(2): 277-302.

Birch, K., \& Siemiatycki, M. 2016. Neoliberalism and the geographies of marketization: The entangling of state and markets. Progress in Human Geography, 40(2): 177-198.

Biygautane, M., Neesham, C., \& Al-Yahya, K. 2019. Institutional entrepreneurship and infrastructure public-private partnership (PPP): Unpacking the role of social actors in implementing PPP projects. International Journal of Project Management, 37(1): $192-219$.

Cabral, S. 2017. Reconciling conflicting policy objectives in public contracting: The enabling role of capabilities. Journal of Management Studies, 54(6): 823-853.

Chambers, E., \& Cox, D. 1967. Discrimination between alternative binary response models. Biometrika, 54(3-4): 573-578.

Chan, A. P., Lam, P. T., Chan, D. W., Cheung, E., \& Ke, Y. 2010. Potential obstacles to successful implementation of publicprivate partnerships in Beijing and the Hong Kong special administrative region. Journal of Management in Engineering, 26(1): 30-40.

Chang, S. J., \& Rosenzweig, P. M. 2001. The choice of entry mode in sequential foreign direct investment. Strategic Management Journal, 22(8): 747-776.

Cohen, J., Cohen, P., West, S., \& Aiken, L. 2003. Applied multiple regression/correlation analysis for the behavioral sciences. Lawrence Erlbaum Associates.

Cohen, W., \& Levinthal, D. 1990. Absorptive capacity: A new perspective on learning and innovation. Administrative Science Quarterly, 35(1): 128-152.

Contractor, F. J., \& Woodley, J. A. 2015. How the alliance pie is split: Value appropriation by each partner in cross-border technology transfer alliances. Journal of World Business, 50(3): 535-547.

Cyert, R., \& March, J. 1963. A Behavioral Theory of the Firm. Prentice-Hall.

Deephouse, D. L., \& Suchman, M. 2008. Legitimacy in organizational institutionalism. The Sage Handbook of Organizational Institutionalism, 49: 77.

Demirag, I., Khadaroo, I., Stapleton, P., \& Stevenson, C. 2011. Risks and the financing of PPP: Perspectives from the financiers. The British Accounting Review, 43(4): 294-310.

Demirag, I., Khadaroo, I., Stapleton, P., \& Stevenson, C. 2012. The diffusion of risks in public private partnership contracts. Accounting, Auditing \& Accountability Journal, 25(8): 13171339.

Di Maddaloni, F., \& Davis, K. 2018. Project manager's perception of the local communities' stakeholder in megaprojects: An empirical investigation in the UK. International Journal of Project Management, 36(3): 542-565.

Doloi, H. 2012. Understanding impacts of time and cost related construction risks on operational performance of PPP projects. International Journal of Strategic Property Management, 16(3): 316-337.

Dunning, J. H. 1998. Location and the multinational enterprise: a neglected factor? Journal of International Business Studies, 29(1): 45-66.
Dykes, B. J., \& Jones, C. D. 2016. public-private partnerships in Africa: Challenges and opportunities for future management research. Africa Journal of Management, 2(3): 381-393.

Dykes, B. J., Stevens, C. E., \& Nandini, L. 2020. Foreignness in public-private partnerships: The case of project finance investments. Journal of International Business Policy, 3(2): 183-197.

Eden, L., \& Miller, S. 2001. Opening the black box: Multinationals and the costs of doing business abroad. Paper presented at the Academy of Management Proceedings.

Edman, J. 2016. Reconciling the advantages and liabilities of foreignness: Towards and identity-based framework. Journal of International Business Studies, 47(6): 674-694.

Elburz, Z., Nijkamp, P., \& Pels, E. 2017. Public infrastructure and regional growth: Lessons from meta-analysis. Journal of Transport Geography, 58: 1-8.

Elsbach, K. D. 1994. Managing organizational legitimacy in the California cattle industry: The construction and effectiveness of verbal accounts. Administrative Science Quarterly, 1: 57-88.

Elsbach, K. D., \& Sutton, R. I. 1992. Acquiring organizational legitimacy through illegitimate actions: A marriage of institutional and impression management theories. Academy of Management Journal, 35(4): 699-738.

Esty, B. 2002. Returns on project-financed investments: Evolution and managerial implications. Journal of Applied Corporate Finance, 15(1): 71-86.

Esty, B. 2004. Why study large projects? An introduction to research on project finance. European Financial Management, 10(2): 213-224.

Fernández-Méndez, L., García-Canal, E., \& Guillén, M. 2015. Legal family and infrastructure voids as drivers of regulated physical infrastructure firms' exposure to governmental discretion. Journal of International Management, 21(2): 135-149.

Finnerty, J. D. 1996. Project financing: Asset-based financial engineering. Wiley.

Finnerty, J. D. 2013. Project financing: Asset-based financial engineering. Wiley.

Flyvbjerg, B., Bruzelius, N., \& Rothengatter, W. 2003. Megaprojects and risk: An anatomy of ambition. Cambridge University Press.

Forbes, D. P. 2005. Managerial determinants of decision speed in new ventures. Strategic Management Journal, 26(4): 355366.

Freeman, R. E. 2010. Strategic management: A stakeholder approach. Cambridge: Cambridge University Press.

Fried, J., Liebers, D., \& Roberts, E. 2020. Sustaining rural hospitals after COVID-19: The case for global budgets. JAMA, 324(2): 137-138.

Geringer, J. M. 1991. Strategic determinants of partner selection criteria in international joint ventures. Journal of International Business Studies, 22(1): 41-62.

Hardcastle, C., Edwards, P., Akintoye, A., \& Li, B. 2005. Critical success factors for PPP/PFI projects in the UK construction industry: A factor analysis approach. Construction Management and Economics, 23(5): 459-471.

Hitt, M., Dacin, T. Levitas, E., Arregle, J., \& Borza, A. 2000. Partner selection in emerging and developed market contexts: Resource-based and organizational learning perspectives. Academy of Management Journal, 43(3): 449-467.

Hoang, H., \& Rothaermel, F. 2005. The effect of general and partner-specific alliance experience on joint $R \& D$ project performance. Academy of Management Journal, 48(2): 332345.

Hoetker, G. 2007. The use of logit and probit models in strategic management research: Critical issues. Strategic Management Journal, 28(4): 331-343.

Hymer, S. 1960. On multinational corporations and foreign direct investment. The Theory of Transnational Corporations. Routledge for the United Nations. 
Jiang, F., \& Stening, B. W. 2013. Do indigenous firms incur a liability of localness when operating in their home market? The case of China. Journal of World Business, 48(4): 478-489.

Jones, G., \& Khanna, T. 2006. Bringing history (back) into international business. Journal of International Business Studies, 37(4): 453-468.

Kacperczyk, A., \& Younkin, P. 2017. The paradox of breadth: The tension between experience and legitimacy in the transition to entrepreneurship. Administrative Science Quarterly, 62(4): 731-764.

Kardes, I., Ozturk, A., Cavusgil, S. T., \& Cavusgil, E. 2013. Managing global megaprojects: Complexity and risk management. International Business Review, 22(6): 905-917.

Kivleniece, I., \& Quelin, B. 2012. Creating and capturing value in public-private ties: A private actor's perspective. Academy of Management Review, 37(2): 272-299.

Kogut, B., \& Zander, U. 1992. Knowledge of the firm, competitive capabilities and the replication of technology. Organization Science, 3(3): 383-397.

Kogut, B., \& Zander, U. 1993. Knowledge of the firm and the evolutionary theory of the multinational corporation. Journal of International Business Studies, 24(4): 625-645.

Kolk, A., Van Tulder, R., \& Kostwinder, E. 2008. Business and partnerships for development. European Management Journal, 26(4): 262-273.

Kostova, T., Roth, K., \& Dacin, M. T. 2008. Institutional theory in the study of multinational corporations: A critique and new directions. Academy of Management Review, 33(4): 994-1006.

Kumaraswamy, M. M., \& Morris, D. A. 2002. Build-operatetransfer-type procurement in Asian megaprojects. Journal of Construction Engineering and Management, 128(2): 93-102.

Kwak, Y., Chih, Y., \& Ibbs, C. 2009. Towards a comprehensive understanding of public private partnerships for infrastructure development. California Management Review, 51(2): 51-78.

Levinthal, D., \& March, J. 1993. The myopia of learning. Strategic Management Journal, 14(S2): 95-112.

Levitt, B., \& March, J. 1988. Organizational learning. Annual Review of Sociology, 14(1): 319-338.

Li, B., Akintoye, A., Edwards, P., \& Hardcastle, C. 2005. Critical success factors for PPP/PFI projects in the UK construction industry. Construction Management and Economics, 23(5): 459-471.

Li, P.-Y., \& Meyer, K. E. 2009. Contextualizing experience effects in international business: A study of ownership strategies. Journal of World Business, 44(4): 370-382.

Linder, S. 1999. Coming to terms with the public-private partnership a grammar of multiple meanings. American Behavioral Scientist, 43(1): 35-51.

Lu, J., Liu, X., Wright, M., \& Filatotchev, I. 2014. International experience and FDI location choices of Chinese firms: The moderating effects of home country government support and host country institutions. Journal of International Business Studies, 45(4): 428-449.

Lundan, S., \& Leymann, G. 2021. Investing in sustainable infrastructure: New directions for international business research. Transnational Corporations, 28(3): 147-157.

Luo, Y. 1997. Partner selection and venturing success: The case of joint ventures with firms in the People's Republic of China. Organization Science, 8(6): 648-662.

Luo, Y., \& Mezias, J. 2002. Liabilities of foreignness: Concepts, constructs, and consequences. Journal of International Management, 8(3): 217-221.

Mahoney, J., McGahan, A., \& Pitelis, C. 2009. Perspective-the interdependence of private and public interests. Organization Science, 20(6): 1034-1052.

Makino, S., \& Tsang, E. W. 2011. Historical ties and foreign direct investment: An exploratory study. Journal of International Business Studies, 42(4): 545-557.

March, J. 1999. The pursuit of organizational intelligence: Decisions and learning in organizations. New York: Blackwell.
Marshall, C., Prusak, L., \& Shpilberg, D. 1996. Financial risk and the need for superior knowledge management. California Management Review, 38(3): 77-101.

Meyer, K. E., \& Peng, M. W. 2005. Probing theoretically into Central and Eastern Europe: Transactions, resources, and institutions. Journal of International Business Studies, 36(6): 600-621.

Mezias, J. 2002. Identifying liabilities of foreignness and strategies to minimize their effects: The case of labor lawsuit judgements in the United States. Strategic Management Journal, 23(3): 229-244.

Miller, K. D. 1992. A framework for integrated risk management in international business. Journal of International Business Studies, 23(2): 311-331.

Miller, S., \& Parkhe, A. 2002. Is there a liability of foreignness in global banking? An empirical test of banks' X-efficiency. Strategic Management Journal, 23(1): 55-75.

North, D. 1990. Institutions, institutional change and economic performance. Cambridge University Press.

Oetzel, J. M., \& Oh, C. H. 2014. Learning to carry the cat by the tail: Firm experience, disasters, and multinational subsidiary entry and expansion. Organization Science, 25(3): 732-756.

Osei-Kyei, R., \& Chan, A. P. 2017. Risk assessment in publicprivate partnership infrastructure projects: Empirical comparison between Ghana and Hong Kong. Construction Innovation.

Osei-Kyei, R., \& Chan, A. 2015. Review of studies on the Critical Success Factors for Public-Private Partnership (PPP) projects from 1990 to 2013. International Journal of Project Management, 33(6): 1335-1346.

Perez-Batres, L. A., \& Eden, L. 2008. Is there a liability of localness? How emerging market firms respond to regulatory punctuations. Journal of International Management, 14(3): 232-251.

Perkins, S. E. 2014. When does prior experience pay? Institutional experience and the multinational corporation. Administrative Science Quarterly, 59(1): 145-181.

Petersen, B., Pedersen, T., \& Lyles, M. 2008. Closing knowledge gaps in foreign markets. Journal of International Business Studies, 39(7): 1097-1113.

PFI. 2014. Project finance international database. Thomson Reuters.

Phillips, R. 2003. Stakeholder legitimacy. Business Ethics Quarterly, 13: 25-41.

Reimann, F., Ehrgott, M., Kaufmann, L., \& Carter, C. R. 2012. Local stakeholders and local legitimacy: MNEs' social strategies in emerging economies. Journal of International Management, 18(1): 1-17.

Sampson, R. C. 2005. Experience effects and collaborative returns in $R \& D$ alliances. Strategic Management Journal, 26(11): 1009-1031.

Sampson, R. 2007. R\&D alliances and firm performance: The impact of technological diversity and alliance organization on innovation. Academy of Management Journal, 50(2): 364-386.

Sawant, R. J. 2010. The economics of large-scale infrastructure FDI: The case of project finance. Journal of International Business Studies, 41(6): 1036-1055.

Sears, D., Rowley, T., \& Reed, J. 1990. Infrastructure investment and economic development. U.S. Department of Agriculture.

Shah, R. H., \& Swaminathan, V. 2008. Factors influencing partner selection in strategic alliances: The moderating role of alliance context. Strategic Management Journal, 29(5): 471494.

Shi, W., \& Hoskisson, R. 2012. Advantages of foreignness: Benefits of creative institutional deviance. Advances in International Management, 25: 99-125.

Siemiatycki, M. 2011. Public-private partnership networks: Exploring business-government relationships in United Kingdom transportation projects. Economic Geography, 87(3): 309-334. 
Sitkin, S. B., \& Pablo, A. L. 1992. Reconceptualizing the determinants of risk behavior. Academy of Management Review, 17(1): 9-38.

Stadtler, L., \& Probst, G. 2012. How broker organizations can facilitate public-private partnerships for development. European Management Journal, 30(1): 32-46.

Suchman, M. C. 1995. Managing legitimacy: Strategic and institutional approaches. Academy of Management Review, 20(3): 571-610.

Suddaby, R., Bitektine, A., \& Haack, P. 2017. Legitimacy. Academy of Management Annals, 11(1): 451-478.

Tang, L., Shen, Q., \& Cheng, E. W. 2010. A review of studies on public-private partnership projects in the construction industry. International Journal of Project Management, 28(7): 683694.

Thomas, C. 1998. Maintaining and restoring public trust in government agencies and their employees. Administration \& Society, 30(2): 166-193.

Tsang, E. W. 2002. Acquiring knowledge by foreign partners from international joint ventures in a transition economy: learning-by-doing and learning myopia. Strategic Management lournal, 23(9): 835-854.

Tushman, M., \& Nadler, D. 1978. Information processing as an integrating concept in organizational design. Academy of Management Review, 3(3): 613-624.

Vaaler, P. M., James, B. E., \& Aguilera, R. V. 2008. Risk and capital structure in Asian project finance. Asia Pacific Journal of Management, 25(1): 25-50.

Wang, Y., Wang, Y., Wu, X., \& Li, J. 2020. Exploring the risk factors of infrastructure PPP projects for sustainable delivery: A social network perspective. Sustainability, 12(10): 4152.

Wells, L., \& Gleason, E. 1995. Is foreign infrastructure investment still risky? Harvard Business Review, 73(5): 44-55.

Wiersema, M., \& Bowen, H. 2009. The use of limited dependent variable techniques in strategy research: Issues and methods. Strategic Management Journal, 30(6): 679-692.

Williams, R. 2009. Using heterogeneous choice models to compare logit and probit coefficients across groups. Sociological Methods \& Research, 37(4): 531-559.

Xiong, W., Zhao, X., Yuan, J.-F., \& Luo, S. 2017. Ex post risk management in public-private partnership infrastructure projects. Project Management Journal, 48(3): 76-89.

Yayavaram, S., Srivastava, M. K., \& Sarkar, M. 2018. Role of search for domain knowledge and architectural knowledge in alliance partner selection. Strategic Management Journal, 39(8): 2277-2302.

Yescombe, E. R. 2002. Principles of project finance. Academic Press.

Zaheer, S. 1995. Overcoming the liability of foreignness. Academy of Management Journal, 38(2): 341-363.

Zaheer, S., \& Mosakowski, E. 1997. The dynamics of the liability of foreignness: A global study of survival in financial services. Strategic Management Journal, 18(6): 439-463.
Zahra, S., \& George, G. 2002. Absorptive capacity: A review, reconceptualization, and extension. Academy of Management Review, 27(2): 185-203.

Zervos, V., \& Siegel, D. S. 2008. Technology, security, and policy implications of future transatlantic partnerships in space: Lessons from Galileo. Research Policy, 37(9): 16301642.

Zhang, L., Zhao, Z., \& Kan, Z. 2019. Private-sector partner selection for public-private partnership projects of electric vehicle charging infrastructure. Energy Science \& Engineering, 7(5): 1469-1484.

Zhang, X. 2005a. Criteria for selecting the private-sector partner in public-private partnerships. Journal of Construction Engineering and Management, 131(6): 631-644.

Zhang, X. 2005b. Critical success factors for public-private partnerships in infrastructure development. Journal of Construction Engineering and Management, 131(1): 3-14.

Zhang, X., \& Kumaraswamy, M. M. 2001. Hong Kong experience in managing BOT projects. Journal of Construction Engineering and Management, 127(2): 154-162.

\section{ABOUT THE AUTHORS}

Bernadine J. Dykes PhD, CPA, is Associate Dean and Associate Professor of Management in the School of Business at Shenandoah University. Her research interests include first-mover advantages, entry timing strategies, and public-private partnerships. She has published research in the Academy of Management Journal, Strategic Management Journal, Journal of International Business Studies, and the Journal of International Management.

Ikenna Uzuegbunam $\mathrm{PhD}$ is Associate Professor of Management at the Howard University School of Business, and visiting Professor at Coal City University, Nigeria. His research interests include resource and cultural determinants of entrepreneurship, innovation, and international strategy. He has published in elite journals including Journal of Business Venturing, Entrepreneurship Theory and Practice, Strategic Entrepreneurship Journal, and Journal of International Management.

Publisher's Note Springer Nature remains neutral with regard to jurisdictional claims in published maps and institutional affiliations.

Accepted by Axèle Giroud, Area Editor, 21 January 2022. This article has been with the authorsfor two revisions. 